\title{
РОЗДІЛ ।
}

\section{ТЕОРЕТИКО-МЕТОДОЛОГІЧНІ ПРОБЛЕМИ РОЗВИТКУ ОСВІТИ ДОРОСЛИХ В УМОВАХ ГЛОБАЛІЗАЦІЙНИХ ТА ІНТЕГРАЦІЙНИХ ПРОЦЕСІВ}

\section{УДК 374.7.091(477)}

DOI: https://doi.org/10.35387/od.2(16).2019.9-19

Аніщенко Олена Валеріївна - доктор педагогічних наук, профресор, завідувач відділу андрагогіки Інституту педагогічної освіти $i$ освіти дорослих імені Івана Зязюна НАПН України

ORCID ID 0000-0002-6145-2321

E-mail: anishchenko_olena@ukr.net

Прийма Сергій Миколайович - доктор педагогічних наук, профресор, профресор кафредри комп'ютерних наук Таврійського державного агротехнологічного університету імені Дмитра Моторного

ORCID ID 0000-0002-2654-5610

E-mail: pryima.serhii@gmail.com

Строкань Оксана Вікторівна - кандидат технічних наук, доцент, завідувач кафредри комп'ютерних наук Таврійського державного агротехнологічного університету імені Дмитра Моторного

ORCID ID 0000-0002-6937-3548

E-mail: oksana.strokan@tsatu.edu.ua

\section{ВИЗНАННЯ РЕЗУЛЬТАТІВ НЕФОРМАЛЬНОГО ТА ІНФОРМАЛЬНОГО НАВЧАННЯ ДОРОСЛИХ: ДОСВІД I ПЕРСПЕКТИВИ}

\begin{abstract}
Анотація. Публікацію присвячено аналізу проблеми визнання результатів неформального та інформального навчання. Конкретизовано понятійно-термінологічний апарат дослідження. Обгрунтовано, що визнання результатів неформального та інформального навчання є вкрай важливим для розвитку суспільства та економіки в цілому, оскільки сприяє зниженню рівня безробіття, забезпечує рівний доступ до здобуття кваліфікацій, а також $\epsilon$ інструментом, що сприяе подоланню невідповідності попиту й пропозицій щодо вмінь і навичок дорослих на ринку праці. Здійснено теоретичне обгрунтування процедури визнання результатів неформального й інформального навчання на основі аналізу національного й зарубіжного досвіду. Проаналізовано окремі аспекти законодавчого забезпечення визнання результатів неформального й інформального навчання в зарубіжній і витчизняній практиці. Стисло охарактеризовано етапи процедури визнання, ї методи та
\end{abstract}


інструменти. Підкреслено, що визнання результатів неформального й інфрормального навчання розглядається в більшості зарубіжних країн як складова освіти упродовж життя, що регулюється на відповідному законодавчому рівні. Проаналізовано етапи процедури визнання, їі методи та інструменти. Розкрито потенціал та значення валідації результів нефоормального й інфрормального навчання у різних сфрерах діяльності. Окреслено сфрери використання визнання результатів неформального й інфоормального навчання. Акцентовано увагу на досвіді використання формального освітнього середовища для перевірки, підтвердження результатів набутих знань, умінь і навичок шляхом неформального та інфоормального навчання. Наголошено на винятково важливій ролі громадського («третього) сектору у сприянні забезпечення валідації неформального та інфрормального навчання дорослих. Обгрунтовано доцільність розроблення національної стратеаії визнання результатів неформального й інформального навчання.

Ключові слова: освіта дорослих, неформальне навчання, інфрормальне навчання, результати навчання, визнання результатів навчання, валідація, ідентифрікація, документування, сертифрікація.

Anishchenko Olena - Doctor of Pedagogical Sciences, Professor, Head of the Department of Andragogy Ivan Ziaziun Institute of Pedagogical and Adult Education of the NAES of Ukraine

ORCID ID http://orcid.org/0000-0002-6145-2321

E-mail: anishchenko_olena@ukr.net

Pryima Serhii - Doctor of Pedagogical Sciences, Professor, Professor at the Department of Computer Science, Dmytro Motornyi Tavria State Agrotechnological University

ID http://orcid.org/0000-0002-2654-5610

E-mail: pryima.serhii@gmail.com

Strokan' Oksana - Candidate of Technical Sciences, Associate Professor, Head of the Department of Computer Science, Dmytro Motornyi Tavria State Agrotechnological University

ORCID ID 0000-0002-6937-3548

E-mail: oksana.strokan@tsatu.edu.ua

\section{RECOGNITION OF THE OUTCOMES OF THE NON-FORMAL AND INFORMAL ADULT EDUCATION: EXPERIENCE AND PROSPECTS}

Abstract. The publication is devoted to the analysis of the problem of recognition of the results of non-formal and informal learning. The conceptual and terminological apparatus of the research is specified. It is justified that recognition of the results of non-formal and informal learning is crucial for the development of society and the economy as a whole, as it contributes to the 
reduction of unemployment, provides equal access to qualifications obtaining, and is also a tool to help overcome the mismatch of supply and demand for adult skills in the labor market. The theoretical substantiation of the procedure of recognition of the results of non-formal and informal learning based on the analysis of national and foreign experience is carried out. Some aspects of legislative support for the recognition of the results of non-formal and informal learning in foreign and domestic practice are analyzed. The steps of the recognition procedure, its methods and tools are briefly described. It is emphasized that the recognition of the results of non-formal and informal learning is considered in most foreign countries as a component of lifelong learning, regulated at the appropriate legislative level. The stages of the recognition procedure, its methods and tools are analyzed. The potential and importance of validation of the results of non-formal and informal learning in various fields of activity are revealed. The areas of application of recognition of results of non-formal and informal learning are outlined. There has been focused on the experience of using a formal educational environment to test, validate the results of acquired knowledge, skills through non-formal and informal learning. The role of the public («third») sector in facilitating the validation of non-formal and informal adult learning is emphasized. The expediency of developing a national strategy for recognizing the results of nonformal and informal learning is substantiated.

Key words: adult education, non-formal learning, informal learning, learning outcomes, recognition of learning outcomes, validation, identification, documentation, certification.

Постановка проблеми, їі актуальність. Серед актуалітетів розвитку освіти дорослих у світі чільне мвсце посідають стандартизація, оцінювання якості та ефективності програм неформального навчання, визнання його результатів. Необхідність визнання результатів неформального навчання актуалізує безліч фракторів, серед яких чільне місце посідають демографрічні, соціальні, економічні, географрічні, політичні тощо. У розвинених країнах світу надання доступу до неформальної освіти, видача національних сертифікатів, що підтверджують результати неформального та інформального навчання, $€$ важливими фракторами створення й розвитку економіки знань. Визнання результатів неформального навчання зазвичай зумовлює позитивний соціальний ефект як для конкретної особистості, яка підвищує таким чином свій статус, так і для суспільства в цілому, його макроекономічного розвитку.

Для України вкрай важливим $є$ усвідомлення на індивідуальному, суспільному й державному рівнях важливості неформального та інфрормального навчання, узгодження та гармонізація освітньої політики провайдерів освітніх послуг у сфрері неформальної освіти і навчання дорослих.

Аналіз останніх досліджень і публікацій. Проблема визнання результатів неформального та інформального навчання, їх ідентифрікація, документування, оцінка та сертифрікація знаходиться в полі зору науковців, 
педагогів-практиків. Цій проблемі приділяють значну увагу як вітчизняні (С. Бабушко, А. Боярська-Хоменко, О. Василенко, І. Татомир, Н. Терьохіна та ін.), так і зарубіжні (М. Афанасьєв, Е. Віллалба, Б. Желєзов, С. Лінс, П. Лукша, К. Манн, Д. Пєсков та ін.) дослідники. Водночас у теорії і практиці законодавчого, організаційно-управлінського та науково-методичного забезпечення освітньої сфери України порушена проблема не знайшла належного відображення. Зокрема, в Україні недостатньо досліджені питання теоретичного обгрунтування процедури визнання результатів неформального та інформального навчання, розроблення національних механізмів визнання таких результатів.

Мета статті полягає в обгрунтуванні необхідності здійснення процедури визнання результатів неформального й інформального навчання в Україні, вивченні, узагальненні досвіду визанння результатів неформального й інформального навчання у національному, зарубіжному освітньому просторі. Публікацію підготовлено відповідно до тематичного плану наукових досліджень Таврійського державного агротехнологічного університету імені Дмитра Моторного (проєкт прикладного дослідження «Теоретичне обґрунтування та розроблення інформаційної системи семантичної ідентифікації, документування та обробки результатів неформального та інформального навчання» (ДР № 0119U000272).

Виклад основного матеріалу дослідження. Як відомо, визнання результатів неформального й інформального навчання може здійснюватися як освітніми установами, так і незалежними інституціями. Різні стейкхолдери прагнуть співпрацювати 3 національними урядами 3 метою розроблення механізмів визнання результатів неформального й інформального навчання. Визнання результатів неформального й інформального навчання має сприяти (Roadmap for implementing a system for validation of non-formal and informal learning, 2015): соціальному залученню громадян; забезпеченню розширеного доступу до сертифікації у сфрері неформальної, інформальної освіти дорослих; підтримці мобільності працівників на основі посилення шансів щодо працевлаштування, кар'єрного розвитку, збереження мотивації до навчання; розширення можливостей у сфері професійної самореалізації (як для зайнятих, так і для самозайнятих осіб); задоволенню потреб роботодавців, підтримці політики розвитку людських ресурсів, спрямованої на підвищення рівня кваліфікації, посилення конкурентоспроможності різних категорій дорослих, підприємств, організацій тощо; забезпеченню інклюзивності суспільства шляхом розширення доступу до формального ринку праці для людей 3 особливими потребами, які перебувають у несприятливих умовах через відсутність офріційно визнаної кваліфікації або внаслідок нестабільності статусу праці тощо.

Передусім акцентуємо увагу на тому, що сутність визнання результатів неформального й інформального навчання полягає в офріційному визнанні за індивідуумом певної кваліфікації в рамках формальної системи кваліфікацій (Железов, 2010). Кваліфікаційні рамки 
визначають набір знань, навичок і умінь, а також їх динамічне поєднання у форматі компетенцій для різного рівня освіти та галузей їх застосування. За Б. Желєзовим, окрім наявності кваліфікаційних рамок, важливою умовою ефективності визнання $є$ забезпечення якості власне процедури визнання, яка може набувати різних форм у різних поєднаннях (спостереження за роботою, співбесіди, іспити, тести тощо). Як зазначено в Рекомендаціях Ради Європи про визнання неформального й інформального навчання (Council of the European Union, 20), визнання результатів навчання (компетентностей), здобутих шляхом неформального та інформально навчання, $\epsilon$ необхідним для доступу громадян до неперервної освіти, ринку праці. Найбільш зацікавленими сторонами у забезпеченні можливостей для визнання результатів неформального й інформального навчання $€$ роботодавці, профспілки, державні заклади, установи тощо, що беруть участь у процесі визнання набутих кваліфікацій, а також служби зайнятості, організації громадянського суспільства тощо. У документах Ради Європи та Європейського центру з розвитку професійної освіти (CEDEFOP) наголошено, що всі зацікавлені сторони прагнуть сприяти упровадженню системного підходу у сфері визнання результатів неформального й інформального навчання з метою посилення візуалізації та цінності його результатів, здобутих поза системою формальної освіти.

Нам імпонує викладене у Рекомендаціях Ради Європи з ключових компетенцій для освіти впродовж життя (Council Recommendation, 21) твердження про те, що підтримка визнання результатів навчання, і зокрема, компетентностей, набутих у різних контекстах, дозволить людині визнати здобуті результати навчання та отримати повну або, якщо це можливо, часткову кваліфікацію. Вона може грунтуватися на наявних домовленостях щодо визнання неформального та інформального навчання, а також Європейській рамці кваліфікацій, що забезпечує загальну (орієнтовну) основу для порівняння рівнів кваліфікацій із зазначенням компетенцій, необхідних для їх досягнення. Водночас розробити національні процедури визнання результатів неформального й інформального навчання досить складно через відсутність уніфікованих інструментів його визнання - ідентифікації, документування, оцінки та сертифікації такого навчання 3 метою їх подальшого використання зацікавленими особами, і зокрема роботодавцями, профспілками, службами зайнятості, постачальниками освітніх послуг, державними та іншими установами, що можуть брати участь у процесі визнання кваліфікації.

Охарактеризуємо більш детально окремі аспекти зарубіжного досвіду визнання результатів неформального й інформального навчання. Так, в американській системі освіти одним із пріоритетів її розвитку $\epsilon$ постійне вдосконалення процедури визнання результатів неформального й інформального навчання, що здійснюється за напрямами: визнання результатів навчання, здобутих як у процесі формального, так і неформального й інформального навчання; визнання компетентностей, набутих на робочому місці; визнання навичок і знань, набутих під час 
роботи у волонтерських та інших організаціях. Процес визнання результатів неформального навчання $є$ децентралізованим - і на рівні штатів, і на рівні навчальних закладів розробляється її законодавче, методичне забезпечення тощо (Терьохіна, 2016, с. 82). У цій країні визнання результатів неформального навчання дорослих здійснюється за допомогою різних методів і процедур відповідно до визначених пріоритетів на рівні штатів, закладів освіти тощо.

Практичний інтерес становить і досвід визнання результатів неформального й інфрормального навчання у країнах Європи. Як зазначено у Звіті Cedefop та Європейської комісії (Cedefop, 2017), у 30 країнах-членах Євросоюзу та Туреччині діє система визнання результатів неформального й інфоормального навчання чи, принаймні, розвивається. Більшість країн $€ С$ мають хоча б одну дієздатну систему, яка дозволяє людині отримати кваліфрікацію шляхом визнання результатів неформального чи інформального навчання. Доцільно наголосити, що механізми визнання результатів неформального та інформального навчання впроваджено не в усіх секторах освіти. Такі механізми більшою мірою діють у профресійній і вищій освіті. Перевірка та підтвердження результатів неформального та інформального навчання за допомогою національних рамок кваліфікацій, а також зарахування кредитів найчастіше зустрічається у закладах вищої освіти. На думку С. Бабушко (Бабушко, 2018, с. 500), ймовірна причина такого стану - у впровадженні Болонського процесу та розширенні сфер використання Європейської кредитно-трансферної системи.

Зазначимо, що низка європейських ініціатив (Європейський саміт (2000, Лісабон), прийняття Меморандуму освіти впродовж життя (2000), резолюції Європейської комісії «Створення європейського простору для освіти впродовж усього життя» (2001), Плану дій до 2025 року Комісії 3 кваліфрікації та мобільності з метою розвитку відкритого й доступного європейського ринку праці, «Пропозицій щодо рішення Європейського парламенту і Ради про єдину рамкову концепцію для підтримки прозорості кваліфікацій і компетенцій» (2003) (Василенко, 2015), директиви Європейського парламенту і Ради ЄС про визнання професійних кваліфікацій (2005), Плану дій з навчання дорослих Європейської комісії (2007), європейських керівних принципів для визнання результатів неформального та інформального навчання Європейської Комісії та CEDEFOP (2009) (CEDEFOP), Рекомендацій Ради Європи щодо валідації неформального та інфрормального навчання (2012) (Council of the European Union, 2012) тощо) сприяють просуванню прогресивних ідей щодо доцільності й необхідності визнання результатів неформального та інфрормального навчання.

Як відомо, мета валідації полягає в отриманні доказів навчання, які потенційно можуть «обмінюватися» на подальше навчання та / або працевлаштування. Це потребує ідентифрікації, документації та оцінки відповідних результатів навчання з метою використання узгодженого та прозорого стандарту. Відповідно до Рекомендацій Ради Європи, валідація 
результатів неформального й інформального навчання передбачає чотири окремі етапи/фрази: ідентифрікацію, документування, оцінювання та сертифікацію (Roadmap for implementing a system for validation of non-formal and informal learning, с. 25; Cedefop, 2015, с. 14). Зазначені етапи/срази застосовуються в різних поєднаннях і співвідношеннях із відображенням мети кожного механізму валідації. Поділ процесу на етапи уможливлює легкість пристосування до конкретних умов; урахування різних індивідуальних потреб, розмаїття завдань при перевірці тощо (Бабушко, 2018), що забезпечує більшу гнучкість процедури визнання. 3 метою підтвердження формальної кваліфікації важливого значення набувають надійність і достовірність етапу оцінювання. В інших випадках, наприклад, у волонтерській роботі, більше уваги приділяється ідентифікації та документального оформлення, а не формальному оцінюванню та сертифікації. Водночас можна очікувати, що ці чотири етапи буде взято до уваги для розроблення всіх механізмах валідації (Cedefop, 2015, с. 15).

На нашу думку, не викликає сумнівів доцільність заохочення здобуття людиною додаткових знань, умінь і навичок із подальшим визнанням передусім професійних компетентностей. Це може стати відповіддю на виклики інформаційного суспільства, глобальної економіки тощо. Водночас слід наголосити, що процес валідації спрямовується на підтвердження як професійних, так й інших компетентностей, в тому числі комунікативних, міжкультурних, громадянських тощо.

У контексті зазначеного вище важливого значення набувають Рекомендації (Cedefop, 2017, с. 45), в яких обгрунтовано необхідність застосування відповідних інструментів визнання результатів неформального й інформального навчання; актуальність спільних європейських інструментів прозорості та визнання, можливої підтримки процесу використання в країнах ЄС інструментів прозорості, серед яких Європаспорт (Europass) та Молодіжний паспорт (Youthpass) (Рекомендації Ради про визнання, 2012, с. 3), що сприяють документальному офрормленню результатів навчання. Отже, серед важливих інструментів профресійної ідентифрікації особистості чільне місце посідає європаспорт (у складі п'яти документів). Цей документ дозволяє узагальнити інформацію про професійні та інші кваліфікації громадян і $є$ прикладом документальної візуалізації раніше набутих кваліфікацій, та уможливлює прозорість кваліфрікацій, відкритість ринків праці всередині $Є С$ тощо. 3 метою типологізації документів про навчання, що відповідають різним компетентностям і кваліфікаціям, Єврокомісією розроблено багатомовний класифрікатор європейських навичок, умінь, кваліфікації та професій (ESCO. European Skills), який сприяє визначенню й класифікації навичок, компетенцій, кваліфікацій і професій, які мають значення для європейського ринку праці, освіти та професійної підготовки.

Акцентуємо увагу на тому, що досягнення прогресу у перевірці набутих компетентностей зумовлює необхідність відокремлення формативної оцінки (виконує важливу роль у багатьох випадках 
(керівництво/адміністрування, консультування, управління персоналом на підприємствах тощо) та підсумкової (Cedefop, 2017, с. 45): (а) формативні підходи в оцінюванні спрямовані на забезпечення зворотного зв'язку $з$ процесом навчання або досвідом навчання, візуалізують сильні й слабкі сторони, забезпечують основу для особистісного розвитку, організаційного удосконалення тощо; (b) сумативні (підсумкові) підходи в оцінюванні та валідації прямо спрямовані на формалізацію й сертифікацію результатів навчання й пов'язані (й інтегровані) з установами (закладами, органами), яким надано повноваження щодо присвоєння кваліфікації. Водночас слід наголосити, що межі формувальної і підсумкової оцінки не завжди $\epsilon$ чіткими (у деяких випадках інструменти можуть бути використані для обох цілей). В обох випадках для кожного потенційно корисного інструмента оцінювання доцільно брати до уваги такі критерії:

- обгрунтованість (інструмент має вимірювати те, що має вимірювати);

- надійність (ступінь досягнення однакових результатів кожного разу, коли кандидат оцінюється за тих самих умов);

- справедливість (ступінь, в якій рішення про оцінювання $€$ вільним від упередженості (контекстна залежність, культура й упередження оцінювача);

- когнітивний діапазон (чи дає інструмент можливість оцінювачам оцінити широту й глибину навчання кандидата);

- придатність для цілей оцінювання (відповідність мети використання інструменту цілям оцінювання).

Важливо розрізняти методи, які спрямовані на отримання доказів (випробування та обстеження, розмовні методи, декларативні методи, спостереження, моделювання, докази, отримані з роботи), а також способи документування та подання доказів (наприклад, «живі докази», резюме, декларації та «портфелі» третіх сторін). Незважаючи на те, що ця диференціація не завжди є чіткою (розроблення портфеля може вважатися доказом певних компетенцій само по собі), вона відображає різницю між методами, які передусім мають на меті зробити видимими індивідуальні компетентності та ті, які візуалізують зібрані докази (Cedefop, 2017, с. 45). Аналіз зарубіжного досвіду визнання результатів неформального й інформального навчання (Терьохіна, 2016) дозволив визначити основні методи його здійснення: тестування, екзамени; дискусії; декларативні методи (ґрунтуються на самооцінюванні кандидатами професійних та особистісних компетентностей); співбесіди; спостереження; моделювання ситуацій; портфоліо індивідуальних освітніх досягнень тощо. Інструменти та методи перевірки мають забезпечувати ясність процедури, її точність та якомога більшу однозначність. Ці критерії покладено в основу процесу валідації та є вирішальними для формування довіри до нього.

Наголосимо, що у нормативно-правовому полі в Україні питання законодавчого регулювання неформальної й інформальної освіти, визнання результатів навчання, отриманих поза системою формальної 
освіти, порушуються віднедавна. Так, статтею 18 Закону України «Про освіту» (2017) передбачено, що органи державної влади та органи місцевого самоврядування створюють умови для фрормальної, неформальної та інформальної освіти дорослих. У статті 8 («Види освіти») Закону викладено визначення формальної, неформальної та інформальної освіти. Відповідно до статті 34 («Кваліфікації»), результати навчання та компетентності, необхідні для присудження освітніх та/або присвоєння профресійних кваліфікацій, можуть досягатися та здобуватися у системі формальної, неформальної чи інформальної освіти. Слід додати, що у 2018 р. утворено Національне агентство кваліфікацій. Питання визнання результатів неформального та інформального навчання певною мірою також регламентується законами України «Про професійний розвиток працівників» (2012), «Про зайнятість населення» (2013), затвердженим «Переліком суб'єктів підтвердження результатів неформального професійного навчання осіб за робітничими професіями» (зі змінами від 03.04.2018р.). В останніх документах, на жаль, йдеться винятково про робітничі профресії.

Висновки та перспективи подальших досліджень. Отже, визнання результатів неформального та інформального навчання в Україні має стати складовою політики освіти впродовж життя та набути законодавчого регулювання, що сприятиме позитивним змінам у профресійному статусі людини впродовж життя, кар'єрному зростанню, розвитку соціальної мобільності громадян, покращенню їх добробуту та якості життя в цілому. Зважаючи на актуальність порушеної проблеми, з метою забезпечення визнання результатів неформального та інформального навчання різних категорій дорослих в Україні доцільно: розробити та запровадити національну стратегію визнання результатів неформального й інфрормального навчання, а також механізми ідентифікації, визнання, оцінювання та підтвердження результатів такого навчання (i, зокрема, здійсненого за програмами короткострокових навчальних курсів, семінарів, тренінгів, заходів з обміну досвідом в Україні та за кордоном, ініційованих інститутами громадянського суспільства, міжнародними та іншими організаціями); розширити перелік професій, за якими може здійснюватися визнання професійних кваліфікацій, отриманих в умовах неформальної та інформальної освіти; розробити і запровадити систему UkrESCO як інтелектуальну надбудову до чинних систем порівняння та оцінки компетентностей з метою співставлення кваліфрікацій з вакансіями, формування паспорту набутих компетентностей тощо.

Перспективними напрямами подальших досліджень $€$ вивчення зарубіжного досвіду обгрунтування, розроблення та впровадження механізмів визнання результатів неформального та інформального навчання.

\section{Список використаних джерел}

Бабушко, С.Р. (2018). Європейський досвід підтвердження результатів неформальної освіти. Концептуальні засади розвитку освіти 
дорослих: світовий досвід, українські реалії і перспективи: зб. наук. пр.; за ред. Кременя В. Г., Ничкало Н. Г. К.: Знання, 495-501.

Василенко, О. (2015). Визнання результатів неформального профресійного навчання - пріоритетний напрям суспільноекономічного розвитку в умовах кризи ринку праці. K. URL: http://lib.iitta.gov.ua/11409/.

Железов, Б. В. Анализ политики стран - членов ОЭСР в области признания результатов неформального образования. (2010). URL: $\quad$ https://iorj.hse.ru/data/2011/01/18/1208078998/Learning_ Recognition.pdf

Рекомендації Ради про визнання неформального й інформального навчання \{SWD(2012) 252, 253 остаточна редакція\}. Комісія Європейського Союзу. СОМ (2012) 485 остаточна редакція. 2012/0234 (NLE). Брюссель, 5.9.2012 p. URL: http://ipq.org.ua/upload/files/files/06_Biblioteka/01_Normativna_ baza/01_Viznznnya_neformalnogo_navchannya/01_Mignarodni_doku menti/council_recommendations_20_dec_2012_ukr.pdf

Терьохіна, Н. О. (2016). Валідація результатів неформальної освіти дорослих у США. Вісник Глухівського національного педагогічного університету імені Олександра Довженка. Серія: Педагогічні науки, 30, 57-63.

Cedefop (2015). European guidelines for validating non-formal and informal learning. Luxembourg: Publications Office. Cedefop reference series; № 104. URL: https://www.cedefop.europa.eu/files/3073_en.pdf.

Cedefop (2017). European Commission. ICF. European inventory on validation of non-formal and informal learning - 2016 update. Synthesis report. Luxembourg: Publications Office. URL: https://www.cedefop.europa.eu/files/4153_en.pdf.

Council of the European Union (2012). Council recommendation of 20 December 2012 on the validation of non-formal and informal learning. Official Journal of the European Union, C 398, 22.12.2012. URL: http://eur-lex.europa.eu/LexUriServ/LexUriServ.do?uri= OJ:C:2012:398:0001:0005:EN:PDF.

Council Recommendation of 22 May 2018 on key competences for lifelong learning (Text with EEA relevance.) ST/9009/2018/INIT OJ C 189, 4.6.2018, p. 1-13. URL: https://ec.europa.eu/education/education-inthe-eu/council-recommendation-on-key-competences-for-lifelonglearning_en.

ESCO. European Skills / Competences, Qualifications and Occupations. URL: https://ec.europa.eu/esco/portal/home

European Skills, Competences, Qualifications and Occupations. URL: https://ec.europa.eu/esco/portal/home

Roadmap for implementing a system for validation of non-formal and informal learning in the former Yugoslav republic of Macedonia. (2015) http://mrk.mk/wp-content/uploads/2015/05/VNFIL-Roadmap_angl-1.pdf 


\section{References (translated and transliterated)}

Babushko, S. R. (2018). European experience in validating non-formal education outcomes. Konceptual'ni zasady' rozvy'tku osvity' dorosly' $x$ : svitovy ’ dosvid, ukrayins'ki realiyi i perspekty'vy' : zb. nauk. pr.; za red. Kremenya V. G., Ny`chkalo N. G. K.: Znannya. 495-501. (In Ukrainian)

Vasylenko, O. (2015). Recognition of non-formal vocational training - a priority of socio-economic development in the labor market crisis. K. URL: http://lib.iitta.gov.ua/11409/. (In Ukrainian)

Zhelezov, B. V. Analysis of OECD member countries' policies in recognition of nonformal education outcomes. (2010). URL: https://iorj.hse.ru/data/2011/01/18/1208078998/Learning_Recognition.pdf (in Russian)

Council Recommendations on the Recognition of Non-Formal and Informal Learning \{SWD (2012) 252, 253 final edition\}. Commission of the European Union. COM (2012) 485 final revision. 2012/0234 (NLE). Brussels, 5.9.2012. URL: http://ipq.org.ua/upload/files/files/06_Biblioteka/01_Normativna_baza/01_Vi znznnya_neformalnogo_navchannya/01_Mignarodni_dokumenti/council_re commendations_20_dec_2012_ukr.pdf (In Ukrainian)

Terokhina, N. O. (2016). Validation of the results of non-formal adult education in the United States. Visny'k Gluxivs'kogo nacional'nogo pedagogichnogo universy`tetu imeni Oleksandra Dovzhenka. Seriya : Pedagogichni nauky'. 30, 57-63. (In Ukrainian)

Cedefop (2015). European guidelines for validating non-formal and informal learning. Luxembourg: Publications Office. Cedefop reference series; № 104. URL: https://www.cedefop.europa.eu/files/3073_en.pdf. (in English)

Cedefop (2017). European Commission. ICF. European inventory on validation of non-formal and informal learning - 2016 update. Synthesis report. Luxembourg: Publications Office. URL: https://www.cedefop.europa.eu/files/4153_en.pdf. (in English)

Council of the European Union (2012). Council recommendation of 20 December 2012 on the validation of non-formal and informal learning. Official Journal of the European Union, C 398, 22.12.2012. URL: http://eurlex.europa.eu/LexUriServ/LexUriServ.do?uri=OJ:C:2012:398:0001:0005:E $\mathrm{N}: \mathrm{PDF}$. (in English)

Council Recommendation of 22 May 2018 on key competences for lifelong learning (Text with EEA relevance.) ST/9009/2018/INIT OJ C 189, 4.6.2018, p. 113. URL: https://ec.europa.eu/education/education-in-the-eu/councilrecommendation-on-key-competences-for-lifelong-learning_en. (in English)

ESCO. European Skills / Competences, Qualifications and Occupations. URL: https://ec.europa.eu/esco/portal/home (in English)

European Skills, Competences, Qualifications and Occupations. URL: https://ec.europa.eu/esco/portal/home (in English)

Roadmap for implementing a system for validation of non-formal and informal learning in the former Yugoslav republic of Macedonia. (2015). http://mrk.mk/wp-content/uploads/2015/05/VNFIL-Roadmap_angl-1.pdf (in English) 